\title{
FACTORS AFFECTING STUDENT ACCEPTANCE OF EVOLUTION THEORY BASED ON GENDER AND EDUCATIONAL BACKGROUND: a case study in Universitas Islam Madura, Indonesia
}

\author{
Shefa Dwijayanti Ramadani ${ }^{1}$, Lukluk Ibana ${ }^{2}$ \\ ${ }^{1,2}$ Pendidikan Biologi, Fakultas Keguruan dan Ilmu Pendidikan, Universitas Islam Madura, 69351, Indonesia \\ shefadwijayanti@gmail.com
}

DOI: $10.21107 /$ jps.v7i1.6846

\begin{abstract}
Evolution is one area on Biology learning that has the most contravention and misconception for many students in various educational regions globally, including Indonesia. This study aimed to identify student's acceptance of the evolutionary theory. The study was conducted using a mixed-method, in which the results of descriptive research were followed by correlational research on the variables studied. Data were collected by using questionnaire and rubric of Measure of Acceptance of The Theory of Evolution (MATE). The results showed that the average MATE score was 65.05 , in which the students tended to have a moderate level of the acceptance of the evolutionary theory. The result showed that sex and religious background correlated with students' acceptance of the evolutionary theory, with a contribution of $49.9 \%$. Thus, these results suggest that evolution is a crucial aspect to be considered in teaching evolution, and there must be an effort to overcome the differences in the acceptance of evolutionary theory in students with different gender and educational backgrounds. Three other factors influence student acceptance of the theory of evolution, namely students' misconceptions, beliefs, and understanding of the nature of science. Therefore, identification of students' prior knowledge is needed to determine the factors that influence students' acceptance in a context.
\end{abstract}

Keywords: acceptance of the evolutionary theory, religious background, gender.

\footnotetext{
${ }^{1}$ Corresponding Author
} 


\section{Introduction}

The fundamental purpose of Biology is to understand and predict the diversity and role of life. The relationship between diversity and function in life can then be studied with evolution. Evolution provides an essential framework for understanding fundamental questions about the world and ourselves. Thoughts about evolution, today, are also growing so that the vital role of evolution as a whole is challenging to express. The implications of the concept of evolution are felt in various fields of life including medicine, pharmacy, public health, agriculture, environmental science, natural resource management, and conservation (Bull \& Wichman, 2001; Davies \& Davies, 2010; Faith et al., 2010; Hendry et al., 2011). Applying the theory of evolution is increasingly widespread in nonbiological research fields such as engineering, computer science, and even the criminal justice system (Losos et al., 2013). All of these reinforce the statement of evolutionary expert Dobzhansky that biology is meaningless unless seen from an evolutionary perspective (1973).

Even though evolution has developed at a much higher level, learning of evolution in various educational environments still faces many obstacles. Evolution is one of the most widely studied biology fields that has generated controversy and has led to rejection and misconceptions in various circles, both among the laity, and academics such as teachers (Athanasiou et al., 2016), students in high schools, and students at universities.

The results of the study revealed by Hofer et al. (2017) shows that the level of student acceptance in higher education towards the evolution theory only reaches $40 \%$, while acceptance in groups outside of higher education is $18 \%$. The low level of student acceptance is quite low because it indicates that students at the university level fail to accept the fundamental theory in natural science. Similar results were also conveyed by Sinatra \& Danielson (2016); the level of acceptance of the theory of evolution is still low and has tended to remain constant over the past few decades. It is a similar condition at Universitas Islam Madura. The majority of students have an educational background in Islamic boarding schools, and they are Muslim; $100 \%$ reject the evolution theory's truth because it is contrary to religious views. Students tend to understand evolution as the process of creating humans from apes. Students even refute Darwin's theory without being based on the correct knowledge of the evolution theory.

Rejection of the theory of evolution is likely to cause failure in understanding the concept of evolution. Therefore, educators need to identify the profile of student acceptance of the theory of evolution. Identification of student acceptance of the theory of evolution so far is still very rarely done. Simultaneously, the information obtained is beneficial as a material for educator consideration in designing lessons about evolution. Thus, an increase in the acceptance of the theory of evolution can increase learning outcomes.

In this study, gender and religious education background variables explain the level of student acceptance of the theory of evolution. We involve gender in research studies because women are assumed to be more spiritual than men, in general. Meanwhile, men are expected to have a higher mastery of knowledge even though the condition has tended to decline in recent years (Miller et al., 2006). The study of religious education background variables is carried out to ascertain whether the rejection of the theory of evolution is related to one's religiosity. Miller et al. (2006) revealed that there is substantial variation in assessing one's level of religiosity. However, this study does not directly measure the level of religiosity but classifies students based on their religious education background.

\section{Research Methods}

We use the Mix Method Research (MMR), which combines the results of descriptive research on the profile of student acceptance about evolution, followed by correlational research on the relationship between gender and religious education background on student acceptance of the theory of evolution. The study involved 59 students in the Biology education department, Universitas Islam Madura, in the academic year 2018/2019. The research was carried out for three weeks before the evolutionary learning process began, and no discussion of evolution was carried out before the research implementation.

Measurement of the acceptance of the concept of evolution is carried out using the MATE (Measure of Acceptance of the Theory of Evolution) rubric developed by Rutledge \& Sadler (2007) (Table 1 and Table 2). The questionnaire consists of 6 evolution concepts, namely: (1) process of evolution, (2) scientific validity of evolutionary theory, (3) evolution of primate, (4) evidence of evolution, (5) scientific community's 
Factors Affecting Student Acceptance of Evolution Theory ...

view of evolution, and (6) age of the earth. The questionnaire's score results were then interpreted with the criteria for the level of acceptance of student evolution (Table 3).

Table 1. MATE (Measure of Acceptance of the Theory of Evolution) Questionnaire

\begin{tabular}{|c|c|c|}
\hline No. & Pernyataan (Indonesian version) & Statement (English version) \\
\hline 1 & Evolusi adalah teori yang benar secara ilmiah. & Evolution is a scientifically correct theory. \\
\hline 2 & $\begin{array}{l}\text { Organisme yang ada pada saat ini merupakan hasil dari } \\
\text { proses evolusi yang telah terjadi selama jutaan tahun. }\end{array}$ & $\begin{array}{l}\text { Organisms that exist today are the result of an evolutionary } \\
\text { process that has taken place over millions of years. }\end{array}$ \\
\hline 3 & $\begin{array}{l}\text { Teori evolusi didasarkan atas spekulasi dan tidak } \\
\text { berdasarkan hasil observasi maupun pengujian secara } \\
\text { ilmiah. }\end{array}$ & $\begin{array}{l}\text { The evolution theory is based on speculation, not based on } \\
\text { observations or scientific testing. }\end{array}$ \\
\hline 4 & $\begin{array}{l}\text { Manusia modern yang ada pada saat ini merupakan hasil } \\
\text { dari proses evolusi yang terjadi selama jutaan tahun. }\end{array}$ & $\begin{array}{l}\text { Today's modern humans are the result of millions of years of } \\
\text { evolutionary processes. }\end{array}$ \\
\hline 5 & Ada sekumpulan data yang mendukung teori evolusi. & $\begin{array}{l}\text { There is a collection of data that supports the evolution } \\
\text { theory. }\end{array}$ \\
\hline 6 & $\begin{array}{l}\text { Kebanyakan ilmuwan menerima teori evolusi sebagai } \\
\text { teori yang benar secara ilmiah. }\end{array}$ & $\begin{array}{l}\text { Most scientists accept evolution as a scientifically correct } \\
\text { theory. }\end{array}$ \\
\hline 7 & Teori evolusi tidak dapat diuji secara ilmiah. & The theory of evolution cannot be tested scientifically. \\
\hline 8 & $\begin{array}{l}\text { Teori evolusi tidak dapat dibenarkan karena tidak sesuai } \\
\text { dengan teori penciptaan dalam agama. }\end{array}$ & $\begin{array}{l}\text { The theory of evolution is wrong because it is incompatible } \\
\text { with the theory of creation in religion. }\end{array}$ \\
\hline 9 & $\begin{array}{l}\text { Organisme yang ada di bumi muncul dalam waktu yang } \\
\text { bersamaan. }\end{array}$ & Organisms on earth appear at the same time. \\
\hline 10 & Umur bumi kurang dari 20.000 tahun & The age of the earth is less than 20,000 years. \\
\hline 11 & $\begin{array}{l}\text { Teori evolusi memberikan makna terhadap } \\
\text { keanakeragaman ciri dan perilaku dari makhluk hidup }\end{array}$ & $\begin{array}{l}\text { The theory of evolution gives meaning to the diversity of } \\
\text { morphology and behavior of living things }\end{array}$ \\
\hline 12 & $\begin{array}{l}\text { Teori evolusi menghasilkan prediksi yang dapat diuji } \\
\text { berkaitan dengan karakteristik makhluk hidup }\end{array}$ & $\begin{array}{l}\text { The theory of evolution produces predictions related to the } \\
\text { characteristics of living things }\end{array}$ \\
\hline 13 & $\begin{array}{l}\text { Organisme yang ada pada saat ini pada dasarnya selalu } \\
\text { berada dalam bentuk yang sama }\end{array}$ & $\begin{array}{l}\text { Organisms that exist today are basically always in the same } \\
\text { form }\end{array}$ \\
\hline 14 & Evolusi adalah teori yang tidak benar secara ilmiah & $\begin{array}{l}\text { Evolution is a theory that is not in accordance with scientific } \\
\text { rules }\end{array}$ \\
\hline 15 & $\begin{array}{l}\text { Banyak komunitas ilmuwan meragukan bahwa evolusi } \\
\text { memang terjadi. }\end{array}$ & Many scientific communities doubt that evolution did occur. \\
\hline 16 & $\begin{array}{l}\text { Teori evolusi yang ada pada saat ini adalah hasil dari } \\
\text { penelitian dan metode ilmiah }\end{array}$ & $\begin{array}{l}\text { The current theory of evolution is the result of research with } \\
\text { scientific methods }\end{array}$ \\
\hline 17 & $\begin{array}{l}\text { Teori evolusi didukung oleh data-data faktual, sejarah, } \\
\text { dan laboratorium. }\end{array}$ & $\begin{array}{l}\text { The theory of evolution is supported by factual, historical, } \\
\text { and laboratory data }\end{array}$ \\
\hline 18 & $\begin{array}{l}\text { Manusia saat ini pada dasarnya selalu berada pada bentuk } \\
\text { yang sama }\end{array}$ & Humans today are like humans in prehistoric years \\
\hline 19 & Umur bumi mencapai 4-5 miliar tahun. & The age of the earth reaches $4-5$ billion years. \\
\hline 20 & $\begin{array}{l}\text { Bukti-bukti yang ada membingungkan untuk } \\
\text { menyimpulkan apakah evolusi benar-benar terjadi. }\end{array}$ & $\begin{array}{l}\text { The available evidence is confusing to reveal whether } \\
\text { evolution happened. }\end{array}$ \\
\hline
\end{tabular}

Table 2. The rubric of MATE Questionnaire

\begin{tabular}{lll}
\hline \multicolumn{1}{c}{ Number of Statement } & Penskoran & \\
\hline $1,2,4,5,6,11,12,16,17,19$ & Strongly Agree & 5 \\
& Agree & 4 \\
& Neutral & 3 \\
& Disagree & 2 \\
& Strongly disagree & 1 \\
\hline $3,7,8,9,10,13,14,15,18,20$ & Strongly disagree & 5 \\
& Disagree & 4 \\
& Neutral & 3 \\
& Agree & 2 \\
\hline
\end{tabular}




\section{Ramadani \& Ibama}

Table 3. The level qualification of evolution concept acceptance base on MATE questionnaire

\begin{tabular}{cc}
\hline MATE Score & Qualification \\
\hline $20-52$ & Very low \\
$53-64$ & Low \\
$65-76$ & Moderate \\
$77-88$ & High \\
$89-100$ & Very high \\
\hline
\end{tabular}

Adapted from Rutledge \& Sadler (2007)

Data collection of students' opinions and perceptions was carried out through the interview method. The aim is to obtain a more comprehensive and in-depth picture of the study being carried out. Specifically, for gender and religious education background variables, a correlation test was conducted to determine the extent of the influence of gender and religious education background, affecting student acceptance of the theory of evolution. Tests carried out through multiple linear regression tests with a significance level of 0.05 .

\section{Result and Discussion}

Universitas Islam Madura (UIM) is a university located in an Islamic boarding school environment in the Pamekasan District, Madura. UIM carries a dual mandate, namely, to build an integrated academic and spiritual Islam. Therefore, students know the science and Islamic religion. Table 4 shows that as many as 59 Biology education study students who were the subjects in this study were all Muslim, and most of them had religious education backgrounds in Islamic boarding schools. In contrast, the number of students is dominated by male students.
Species have changed over a long period and can be proven by evidence of evolution. The development of biology in the molecular field has also provided detailed information on genetic diversity to explain the kinship and evolutionary processes of an organism. Even though quite a lot of scientific explanations have been revealed through various studies of evolution, but evolution is still a debate, especially among UIM students.

Generally, the results of the study show a variety of students' perceptions of the acceptance of the theory of evolution, which starts from a very low acceptance rate $(10.71 \%)$, low $(35.71 \%)$, moderate $(41.07 \%)$, and high $(12.50 \%)$. There were no students who showed very high acceptance at the beginning of learning (Table 5). Meanwhile, the average MATE score classically in one class is 65.05 or at a moderate level of acceptance. The level of acceptance is similar to the results of Rissler et al. (2014), Ingram \& Nelson (2006), and Glaze \& Goldston (2019). On the other hand, the score is still lower than the level of acceptance of the evolution of students reported by Allmon (2011), Dunk et al. (2017), and Metzger et al. (2018).

Table 4. Demographic of Research Subject

\begin{tabular}{cccc}
\hline Demographic & & Number of Students & Frequency (\%) \\
\hline \multirow{2}{*}{ Educational Background } & Islamic Boarding School & 43 & 72.88 \\
& Non-Islamic Boarding School & 16 & 27,12 \\
\multirow{2}{*}{ Gender } & Male & 40 & 67.79 \\
& Female & 19 & 32.20 \\
\hline
\end{tabular}

Table 5. The level of acceptance of the theory of evolution

\begin{tabular}{cccc}
\hline Level of Acceptance & MATE Score & Number of Students & Frequency $(\%)$ \\
\hline Very low & $20-52$ & 6 & 10.71 \\
Low & $53-64$ & 20 & 35.71 \\
Moderate & $65-76$ & 23 & 41.07 \\
High & $77-88$ & 7 & 12.5 \\
Very high & $89-100$ & 0 & 0 \\
\hline
\end{tabular}


Factors Affecting Student Acceptance of Evolution Theory ...

Table 6. The results of the regression analysis between sex and religious education background with acceptance of the theory of evolution

Model Summary

\begin{tabular}{lrrrr}
\hline Model & R & R Square & Adjusted R Square & \multicolumn{2}{c}{$\begin{array}{c}\text { Std. Error of the } \\
\text { Estimate }\end{array}$} \\
\hline 1 & $.707^{\mathrm{a}}$ & .499 & .480 & 7.62845 \\
\hline
\end{tabular}

a. Dependent Variable: Acceptance of Evolition

b. Predictors: (Constant), Educational background, Gender

\begin{tabular}{|c|c|c|c|c|c|c|}
\hline \multicolumn{7}{|c|}{ ANOVA } \\
\hline Model & & Sum of Squares & Df & Mean Square & $\mathrm{F}$ & Sig. \\
\hline \multirow[t]{3}{*}{1} & Regression & 3074.600 & 2 & 1537.300 & 26.417 & $.000^{\mathrm{b}}$ \\
\hline & Residual & 3084.239 & 53 & 58.193 & & \\
\hline & Total & 6158.839 & 55 & & & \\
\hline
\end{tabular}

a. Dependent Variable: Acceptance of Evolition

b. Predictors: (Constant), Educational background, Gender

\begin{tabular}{|c|c|c|c|c|c|c|}
\hline \multicolumn{7}{|c|}{ Coefficients } \\
\hline \multirow[b]{2}{*}{ Model } & & \multicolumn{2}{|c|}{ Unstandardized Coefficients } & $\begin{array}{l}\text { Standardized } \\
\text { Coefficients }\end{array}$ & \multirow[b]{2}{*}{$\mathrm{t}$} & \multirow[b]{2}{*}{ Sig. } \\
\hline & & B & Std. Error & Beta & & \\
\hline \multirow[t]{3}{*}{1} & (Constant) & 36.936 & 4.421 & & 8.355 & .000 \\
\hline & Gender & 5.704 & 2.262 & .246 & 2.522 & .015 \\
\hline & Educational Background & 16.868 & 2.420 & .679 & 6.971 & .000 \\
\hline
\end{tabular}

a. Dependent Variable: Acceptance of Evolition

The results of further identification through the multiple regression test in Table 6 reveal that there is a significant relationship between gender $(\mathrm{p}=0.015)$ and religious education background $(\mathrm{p}$ $=0,000)$ with acceptance of the concept of evolution. In addition, it can also be seen the magnitude of the correlation coefficient $(\mathrm{R})$ of 0.707 with a reliability value (R2) of 0.499 . Thus, it can be seen that gender and educational background contributed to the acceptance of evolution in the amount of $49.9 \%$. In comparison, the remaining $50.1 \%$ was influenced by other variables not examined in this study.

Students who have a very low acceptance level up to a moderate level of acceptance; actually do not understand the concept of evolution correctly. Three causative factors can explain this condition. Firstly, students misconceptions, one of which is Darwin's theory which explains that humans originate from apes. Meanwhile, students' understanding of the development of the theory of evolution, the evidence for evolution, and the mechanism of evolution are still low.

The big gap that arises from Darwin's theory of evolution is that at that time, he did not yet have a good explanation of how variations occur in living things and bequeathed to their offspring. This gap can only be revealed at the beginning of the 20th century through the theory of Genetics. It explains how a character can be inherited through gene transmission and genetic mutations. In the next period, molecular mechanisms of gene transmission and genetic variation can increasingly be understood as a result of biochemical interactions involving DNA and RNA. On this basis, it can be understood that the conceptions held by many groups, including students who are so opposed to the theory of evolution, do not yet know the concept of evolution precisely. Darwin never even called humans derived from apes as alleged by many groups.

Alters \& Nelson (2002) explain that the results of research involving students in learning Biology in schools show that there is a very continuous relationship between the factors that influence the process of students' conceptual change in evolutionary learning. For example, previous conceptions of evolution, scientific epistemology, religious orientation, acceptance of evolution, and scientific orientation, namely the extent to which students live their lives by carrying out activities around scientific activities. The learning patterns received by previous students also determine the acquisition of concepts and the success of students during the last learning process.

The results of further identification show that the group of students with very low to moderate acceptance rates generally accept conventional evolutionary learning at the previous educational level. Alters \& Nelson (2002) firmly state that education that is carried out nonstop through lectures is not an effective method of increasing students' understanding and retention of the concepts being studied. In addition, Wallin et al. (2001) revealed that students of different ages, cultural backgrounds, and educational settings experienced difficulties in understanding biological evolution, while not much understanding was 


\section{Ramadani \& Ibama}

improved through traditional teaching. Conversely, a variety of active learning strategies (Discovery learning, discussions, research projects, and webbased simulations) are reported to enhance students' understanding of concepts. Learning becomes more meaningful for students to understand and contribute to improving student misconceptions (Alters \& Nelson, 2002; Fauzi \& Ramadani, 2017; Fiedler et al., 2018).

Secondly, students believe that all diversity, including human presence on earth, is solely the power of God. Therefore, the theory of evolution cannot be accepted at all, even considered different from religious views. Evolution never denies the existence of God. Some scientists believe that God plays a role in the process of evolution. Evolution is even considered to be God's way of creating diversity in living things today (Amin, 2015). The most recent sentence in Darwin's work entitled The Origin of Species by Means of Natural Selection (1859) states: "There is a grandeur in this view of life, with its several powers, having been originally breathed by Creator into a few forms or one, and that, while the planet has gone cycling on according to the fixed law of gravity, the form is so simple the beginning of the most beautiful and most beautiful endless have been and are being evolved."

The background of the religious education of students obtained through boarding school education is an excellent provision for a Biologist because the real command to study Biology has been stated in the Qur'an. Amin (2015) revealed that there are basically two things that can be a guide in life for a Muslim. First, the Qur'an as a collection of God's Revelations to the Prophet Muhammad that comes from the realm of supernatural but very much guides us in learning the real world. Second, the universe with all its contents in the form of the real world, but once studied further and sincerely, will guide us to learn about the natural world until we become aware of the majesty of God Almighty, the creator of the universe. Therefore, the importance of students being able to violate science and religion.

Finally, students' understanding of the nature of science (NOS) is lack. Students do not understand well how to think, work, and the nature of truth from science. An understanding of NOS has also been widely studied to increase student acceptance of the theory of evolution. Lombrozo et al. (2008) revealed that for more than three decades, the results of studies showed that efforts in understanding the goals, processes, and limitations in science led to an increase in the acceptance of evolution. Other support for the importance of teaching NOS also comes from the study of Pigliucci (2008) that the rejection of the theory of evolution generally comes from creationist arguments, which often contain misconceptions about the nature of science. On the contrary, an understanding of how to think, work, and the nature of scientific truth need to be taught so that a good understanding of the epistemology of the scientist grows.

Science, including evolution, has truths that are different from religion. The purpose of science is to explain a natural phenomenon logically based on observations made by humans. The theory of evolution has very well described natural phenomena of a diversity of living things and the existence of fossils found at different ages. In this case, science and evolution have empirical truth accepted as logical under observed facts. The truth is relative because science is something that develops dynamically. Religion has absolute truth and is dogmatic. Studying evolution requires a wise attitude because of both stands on a different footing.

Together, these three factors reinforce an incorrect student conception of evolution, giving rise to controversy regarding the evolution of living things. These three factors are the findings of this study, which can be developed into further research. For example, many fundamental concepts that are important to understand by students to succeed in understanding the next concept that will be studied. However, if the fundamental concepts are not well understood, how can students understand the next concepts that are built from these fundamental concepts in the future? Therefore, it is important to instill basic concepts that are accompanied by empirical evidence and related to religious studies.

\section{Conclusion}

The level of student acceptance of the theory of evolution varies from very low acceptance rates $(10.71 \%)$, low $(35.71 \%)$, moderate $(41.07 \%)$, to high admission rates (12.5\%). In addition, the results of the study also revealed that there were significant differences between students' acceptance of the theory of evolution in different gender $(p=0.015)$ and various religious education settings (Islamic boarding school or nor) $(\mathrm{p}=$ $0,000)$. Both of these variables are known to contribute $49.9 \%$ to student acceptance of the theory of evolution. There are three influencing factors, namely student misconception, student beliefs, and student understanding of NOS. The process of identifying student acceptance of 
Factors Affecting Student Acceptance of Evolution Theory ...

evolution theory is important to do before teaching the concept of evolution. Acceptance or rejection of the theory of evolution that is scientifically valid can affect students' understanding. Finally, this kind of research is exciting to be done by involving research subjects with different cultural backgrounds, religious backgrounds, and educational levels in other regions to reveal more about the profile of the population's acceptance of the theory of evolution.

\section{References}

Amin, M. (2015). Biologi sebagai sumber belajar untuk generasi masa kini dan mendatang yang berintegritas dan berperadaban tinggi. Makalah disampaikan saat Pidato Pengukuhan Jabatan Guru Besar dalam Bidang Ilmu Biologi FKIP Universitas Negeri Malang.

Allmon, W.D. (2011). Why Don't people think evolution is true? Implications for teaching, in and out of the classroom. Evo Edu Outreach, (4): 648-665. DOI: 10.1007/s12052-011-0371-0.

Alters, B.J. \& Nelson, E. (2002). Perspective: Teaching Evolution in Higher Education. Evolution, 56(10): 1891-1901. DOI: https://doi.org/10.1111/j.00143820.2002.tb00115.x.

Athanasiou, K., Katakos, E., \& Papadopoulou. (2016). Acceptance of evolution as one of the factors structuring the conceptual ecology of the evolution theory of Greek secondary school teachers. Evo Edu Outreach, 9(7). DOI: 10.1186/s12052016-0058-7.

Bull, J., Wichman, H.A. (2001). Applied evolution. Annu Rev Ecol Syst, 32(18): 183-217.

Davies, J. \& Davies, D. (2010). Origins and evolution of antibiotic resistance. Microbiol Mol Biol Rev, 74: 417-433.

Dobzhansky, T. (1973). Nothing in Biology makes sense except in the light of evolution. American Biology Teacher, 35(3): 125129.

Dunk, R.D.P., Petto, A.J., Wiles, J.R., Campbell, B.C. (2017). A multifactorial analysis of acceptance of evolution. Evol Educ Outreach, 10(4). DOI: https://doi.org/10.1186/s12052-0170068-0.

Faith, D.P., Magallon, S., Hendry, A.P., Conti, E., Yaharam T. (2010). Ecosystem services: an evolutionary perspective on the links between biodiversity and human well- being. Curr Opin Environ Sustainability, 2: 1-9.

Fauzi, A. \& Ramadani, S.D. (2017). Learning the genetics concepts through project activities using Drosophila melanogaster: a qualitative descriptive study. Jurnal Pendidikan Biologi Indonesia, 3(3): 238247.

DOI: https://doi.org/10.22219/jpbi.v3i3.4897.

Fiedler, D., Trobst, S., Großschedl, J., \& Harms, U. (2018). EvoSketch: Simple simulations for learning random and probabilistic processes in evolution, and the effects of instructional support on learners' conceptual knowledge. Evo Edu Outreach, 11(15). DOI: https://doi.org/10.1186/s12052-0180089-3.

Glaze, A. \& Goldston, J. (2019). Acceptance, Understanding, \& Experience: Exploring obstacles to evolution education among advanced placement teachers. The American Biology Teacher, 81(2): 71-76. Doi: https://doi.org/10.1525/abt2019.81.2.71.

Hendry, A.P., Kinnison, M.T., Heino, M., Day, T., Smith, T.B., Fitt, G., ... \& Gilchrist, G. (2011). Evolutionary principles and their practical application. Evolutionary Application, 4(2): 159-183. DOI: https://doi.org/10.1111/j.17524571.2010.00165.x.

Hofer, B. K., Lam, C.F., \& Delisi, A. (2017). Understanding evolutionary theory, Chapter 5. Epistemology and science education: understanding the evolution $v$ s. intelligent design controversy. New York: Routledge. DOI: https://doi.org/10.4324/9780203839638.

Ingram, E. L. \& Nelson, C. E. (2006). Relationship between achievement and students' acceptance of evolution or creation in an upper-level evolution course. Journal of research in science teaching, 43(1), 7-24. DOI: https://doi.org/10.1002/tea.20093.

Metzger, K. J., Montplaisir, D., Haines, D., \& Nickodem, K. (2018). Investigating undergraduate health sciences students' acceptance of evolution using MATE and GAENE. Evo Edu Outreach, 11(10): 118. DOI: https://doi.org/10.1186/s12052018-0084-8.

Miller, J. D., Scott, E.C. \& Okamoto, S. (2006). Supporting online material for public acceptance of evolution. Science, 313(5788): 765-766. DOI: 10.1126/science. 1126746 . 


\section{Ramadani \& Ibama}

Lombrozo, T., Thanukos, A., \& Weisberg, M. (2008). The importance of understanding the nature of science for accepting evolution. Evo Edu Outreach, (1): 290298. DOI: 10.1007/s12052-008-0061-8.

Losos, J.B., Arnold, S.J., Bejerano, G., Brodie, E.D..... \& Turner, T.L. (2013). Evolutionary biology for the 21st century. PLoS Biology, 11(1), e1001466. DOI:

https://doi.org/10.1371/journal.pbio.1001 466.

Pigliucci, M. (2008). Denying evolution: Creationism, scientism, and the nature of science. Sunderland, MA: Sinauer Associates, Inc.

Rissler, L., Duncan, S., \& Caruso, N. (2014). The relative importance of religion and education on university students' views of evolution in the deep South and state science standards across the united states. Evol Educ Outreach, 7(24). DOI: https://doi.org/10.1186/s12052-0140024-1.

Sinatra, G.M. \& Danielson, R.W. (2016). Adapting evolution to a warming climate of teaching and learning. Evolutionary Perspectives on Child Development and Education, 271-290. DOI: 10.1007/9783-319-29986-0_11.

Wallin, A., Hagman, M. \& Olanderm C. (2001). Teaching and learning about biological evolution: Conceptual understanding before, during, and after teaching. (Online). Downloaded from https://gupea.ub.gu.se/bitstream/2077/19 219/1/gupea_2077_19219_1.pdf. 